\title{
A Systematic Review on Bilingualism and Language Processing from 2015-2019
}

\author{
SOH, OR-KAN \\ School of Language Studies \& Linguistics \\ Faculty of Social Sciences \& Humanities \\ Universiti Kebangsaan Malaysia \\ HAZITA AZMAN \\ School of Language Studies \& Linguistics \\ Faculty of Social Sciences \& Humanities \\ Universiti Kebangsaan Malaysia \\ hazita@ukm.edu.my \\ HO, SU-MEI \\ School of Language Studies \& Linguistics \\ Faculty of Social Sciences \& Humanities \\ Universiti Kebangsaan Malaysia
}

\begin{abstract}
Over the past few decades, research on bilingualism has been extensively covered but still leaves room for much to be discovered especially in the context of language processing. There is a lack in systematic review on studies that examine the trends, effects, methodological approaches, challenges and limitations on bilingualism in relation to language processing. Therefore, this article aims to offer current understanding on bilingualism and language processing through a process of a critical analysis and synthesis. A total of 20 articles published from 2015-2019 in peer-reviewed journals both abroad and locally were selected to be included in this review for content analysis. Hence, this paper attempts to give a systematic report on the findings categorized by trends, effects, methodological approaches, challenges and limitations. Few main findings emerged: (a) An increasing trend in the study on internal language processing and individual factors affecting bilingualism; (b) The existence of inconsistent effects; (c) The need to re-evaluate methodological approaches; and (d) The lack of research conducted in Malaysia. This review also provides suggestions and opportunities for future research in bilingualism and language processing.
\end{abstract}

Keywords: systematic review; bilingualism; language processing; qualitative method; challenges

\section{INTRODUCTION}

The amount of extensive research done on bilingualism over the last few decades has not only shown to be rigorous, but that there is still much to be discovered about bilinguals. This is because bilingualism is a multifaceted phenomenon which is reflected even in the definition of bilingualism itself as there is no universal definition due to the various dimensions that needs to be taken into account (Hamers \& Blanc, 1983). According to Hamers and Blanc (1983), bilingualism has been generally defined as the ability to access or use more than one language as a means of communication. Furthermore, language has been considered to have strong ties with cognition and the brain. Valian (2015) has revealed that the link between language and the mind can be explained through bilingualism and cognition. This means that in language processing, the study of bilingualism aims to discover how the bilingual experience can assist or hamper cognition especially the executive function which influences language performance. Valian further established that an explicit hypothesis, which is the existence of an essential device needed for 


\section{L: The Southeast Asian Journal of English Language Studies - Vol 26(1): 18 - 31 \\ http://doi.org/10.17576/3L-2020-2601-02}

bilinguals to manoeuvre between two languages and inhibit the languages not in use in order to produce fluent language performance, is the fundamental of all research regarding bilingualism and executive function.

This underlying mechanism deduced by Valian (2015) was first proposed by Green (1998), known as Inhibition Control (IC) which sparked off various research showing advantages of bilinguals compared to monolinguals in areas extending even beyond language processing which is widely known as the bilingual advantage (Bialystok, 1999). Since then, an extensive quantity of literature that examined the hypothesis regarding the bilingual advantage have suggested that there are advantages to the bilingual experience such as greater mental flexibility (Bialystok \& Martin, 2004), problem solving skills (Leikin, 2012) and even the greater plasticity in the physical structure of the brain which can help delay the onset of Alzheimer's disease (Antoniou, 2019; Bialystok, Craik \& Freedman, 2007). Conversely, in recent years, a substantial amount of research indicating no bilingual advantage or even opposing results have also emerged (Costa, Hernandez, Faidella, \& Galles, 2009; Sandoval, Gollan, Ferreira \& Salmon, 2010). Valian has attempted to explain the inconsistencies in results by suggesting that such inconsistencies are to be expected due to the fundamental vagueness in understanding about which exact section of the executive function is activated in the tasks used therefore producing uncertainty about how different variations of the tasks used might have an effect on the results. Valian also cited individual differences such as education, social economic status, leisure activities and musical training as factors for inconsistent results as these factors might contribute to the enhancement of the executive function. On the other hand, Bruin, Treccani and Sala (2015) have concluded that such inconsistencies exist because of the existing publication bias which promotes the publishing of research with only positive results.

Existing literature reviews have extensively covered many aspects of bilingualism by synthesizing trends as well as contributing an analysis of findings (Valian, 2015). However, the substantial amount of published research reporting on the various aspects of bilingualism such as the advantages, disadvantages, limitations and challenges have indicated a lack of condensed and focused research in particular areas of bilingualism especially over the past 5 years. This means that there is a lack of systematic research on bilingualism especially in relation to language processing. Thus through a synthesis of 20 selected articles on studies conducted internationally and in Malaysia, this study aims to report the current understanding as well as to fill a gap in the current research on bilingualism and language processing. Additionally, this study also analyses the current literature in the context of Malaysia as bilingualism is deeply rooted in the historical and educational development of Malaysia (Chan \& Abdullah, 2015). Therefore, within this context, this review is guided by the following research question: "What is the current understanding about bilingualism in relation to language processing over the last five years?"

\section{RESEARCH METHODS}

A synthesis on bilingualism research establishes significant relationships from current literature as well as provides conclusions and theories for further research and practice (Kroll, Dussaias, Bice $\&$ Perrotti, 2015). The current review uses a qualitative synthesis approach in synthesizing the studies collected. Suri and Clarke (2009) have defined qualitative research synthesis as the synthesizing of qualitative research using systematic means with the intent to increase accountability, credibility, and transferability of synthesis findings. 


\section{L: The Southeast Asian Journal of English Language Studies - Vol 26(1): 18 - 31 \\ http://doi.org/10.17576/3L-2020-2601-02}

The synthesis in this review went through three distinct phases (Figure 1) - Phase 1: search and inclusion, Phase 2: individual study review and Phase 3: content analysis through cross-study comparison and analysis which is modelled after the research conducted by Baran (2014). In phase 1 , the purpose was to employ a consistent manner in searching and selecting through an inclusion and exclusion criteria the most relevant journals for this review. A search by employing keywords such as "bilingualism" and "language processing" or "language processing" and "bilingual" or "bilingual" and "language" in the Web of Science (WOS) complete database produced 730 results. In order to guarantee reliability, a guideline for carrying out literature reviews proposed by Webster and Watson (2002) was used in which the authors proposed that contributions published in leading journals should be a starting point when ascertaining relevant literature. Therefore, a second manual search was later conducted in high-ranked journals in the field of bilingualism namely International Journal of Bilingualism and Bilingualism: Language and Cognition. To further ensure reliability, the search results were then examined using an inclusion and exclusion criteria as proposed by Bacca, Baldiris, Fabregat, Graf and Kinshuk (2014). In order to refine the search results, articles were selected based on general and specific inclusion criteria as well as exclusion criteria by considering the research questions, time frame as well as scope of the relevant studies. The overarching general criteria entailed studies published between 2015 and 2019 as well as studies that centres around bilingualism in language processing. Additionally, relevant criteria that were specified in the scope of search included studies that report on the advantages, disadvantages, factors, limitations and challenges of bilingualism on language processing; studies that report on cognition and language processing in relation to bilingualism; studies that report on assessment methods for bilingualism on language processing and also studies done locally were included in this review. Important to note that, studies that met the exclusion criteria and are not recognized in the journals as "Articles" such as book chapters as well as studies which only included the key terms which are "bilingualism" and "language processing" in their references were excluded. The relevance and reliability of the chosen articles was also examined by conducting a manual search in the leading journals. Therefore, 20 articles published from 20152019 in peer-reviewed journals which covered the advantages, disadvantages, factors, methods, limitations and challenges of bilingualism on language processing were selected to be included in this review.

In phase 2, an analysis of the 20 articles was carried out. The articles were examined through an analytic research synthesis table by coding with notations meta-categories of language processing context such as definition of bilingualism, effects and outcomes of bilingualism. Notations regarding methodology which included the aim of the study, participant information and test employed or data sources were also included in order to aid in comparisons among the studies (see Table 1 in Appendix). In the final part of this research which is phase 3, a content analysis is carried out through a directed approach which is suggested by Hsieh and Shannon (2005) to be informed by a relevant theory or findings. Therefore, the chosen articles were then compared and analysed within these determined categories and reported as findings. The data gathered were examined "to consider themes, shapes, and organization of research ideas present in the overall literature" (Opfer \& Pedder, 2011). The categories employed which portrayed differences as well as similarities are trends, advantages and disadvantages of bilingualism, methodological approaches, challenges and limitations in relation to language processing. 


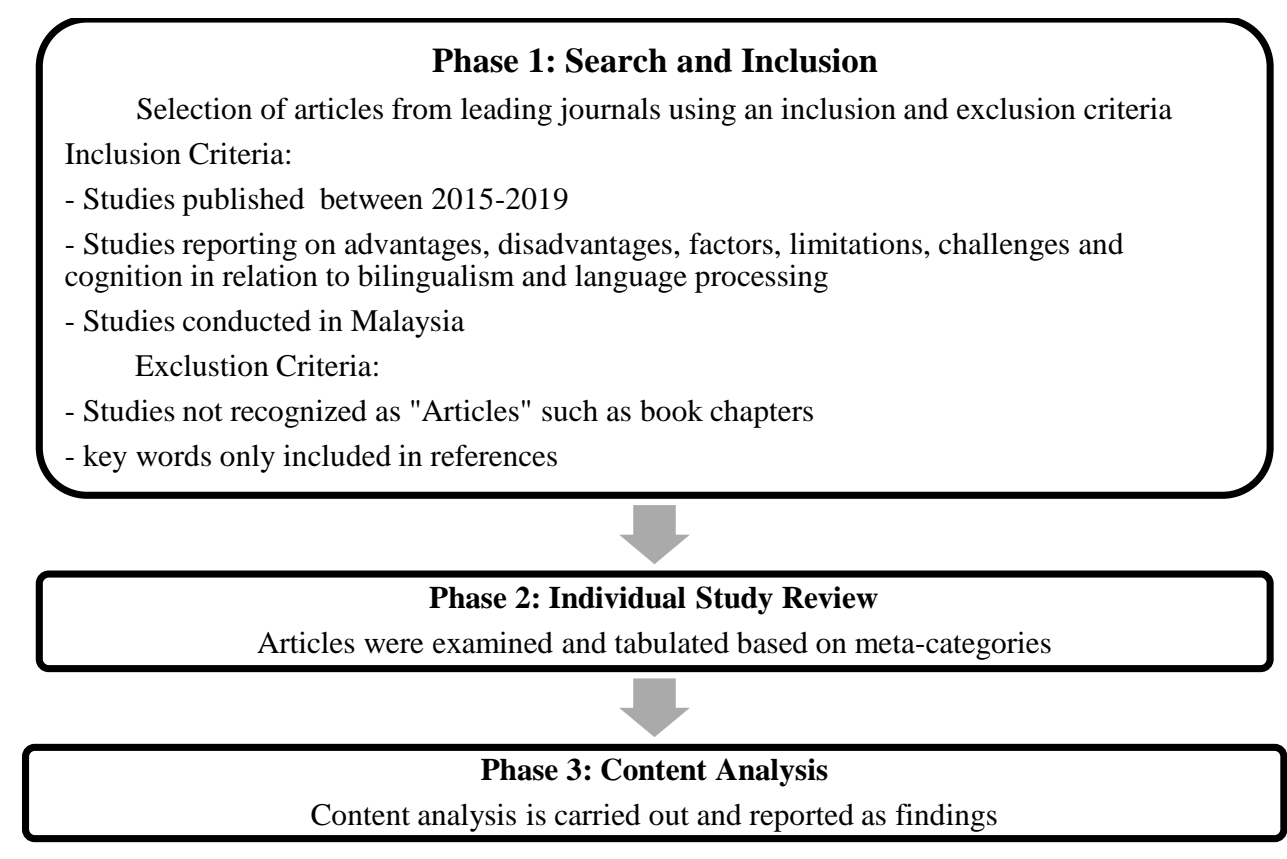

FIGURE 1. Research Procedures

\section{FINDINGS}

Through the research synthesis conducted on the selected 20 articles about bilingualism and language processing, few main findings emerged that can inform the methodology and perspectives on bilingualism research in differentiated contexts. These findings are reported below in terms of trends, outcomes, methodological approaches, challenges and limitations.

\section{TRENDS IN THE BILINGUALISM AND LANGUAGE PROCESSING LITERATURE}

The 20 articles that were chosen to be analysed were set with a time frame of 2015-2019 in order to obtain updated and relevant literature. Within the time period of 5 years, an equal amount of literature was selected for each year in order to analyse the trends of the literature in each particular year. Research done in Malaysia was also included in each year in order to determine the overall trend in the local scene.

Overall, the aim of the studies analysed in this review can be categorized into three main types. The first is the effects of bilingualism on external language processing which is language production. The second category is the effects of bilingualism on internal language processing which has to do with executive function or cognition and the brain. The third would be the factors that affect the bilingual experience in language processing. More than half of the research conducted over the period of 2015-2019 have been dedicated to finding out the effects of bilingualism on internal language processing such as the benefits of bilingualism on executive function, cognition or the physical structure of the brain which affects language processing $(\mathrm{n}=$ 8). A significant but slightly lesser amount of studies conducted aims to find out the effects of bilingualism on external language processing such as verbal interference control, code-switching, phonetic sensitivity and plural expressions $(n=6)$. Only a small number of research has focused on the factors that affect bilingualism and language processing $(n=3)$. Only one of the research 


\section{L: The Southeast Asian Journal of English Language Studies - Vol 26(1): 18 - 31 \\ http://doi.org/10.17576/3L-2020-2601-02}

conducted consist of aiming to find out both internal and external language processing. The remaining two studies were not really centred on bilingualism and language processing but geared towards bilingualism and education policy including teacher's and student's perception. However, they were selected as they were local articles which were important to identify the local trends.

Delving into the trends of each year, it is apparent that the focus of research towards the effects of bilingualism on internal language processing has increased throughout the years. Between 2015 and 2016, only 1 article each year was found to have reported on internal language processing and the rest of the 6 articles were focused on external language processing. However, a shift in 2017 saw a significant increase in articles (3 out of 4) about how language is processed internally. Subsequently in 2018, the focus shifted to studies on factors that affect bilingualism and language processing as well as the teacher's and student's perception. Unlike the previous year, only 1 article was found to report on internal language processing. A similar trend can also be observed in the year 2019 in which 2 articles have purposed to study internal language processing while the other 2 centres on the external effects as well as factors. In contrast, the overall trend in the study of bilingualism and language processing locally over the period of 20152019 was not apparent as studies related to bilingualism were mostly centred on education. Only 2 articles were found to be close to reporting on the effects and factors of bilingualism in relation to language processing.

In relation to the methodologies employed by the studies reviewed, it was found that majority of the investigations employed the qualitative approach $(n=9)$ as well as the mixed $=$ method $(n=5)$ designs. However, a few were investigated as case studies $(n=4)$, while the remaining studies $(n=2)$ employed the quantitative method. Relatedly, the range of research participants ranged from infants (age 16 months) children (provide age range age 4-13) to adults (provide age range age 20-35) and older adults (provide age range age 59-83). As for the participants, $25 \%$ of the studies focused on children as their participants while $30 \%$ of articles aimed to study on adults. Only 1 article was found to study on older adults and another 1 article employed both children and adults as their participants. Additionally, data sources comprised journal articles, performances of various tasks, observations via video or audio recording, questionnaires as well as Magnetic Resonance Imaging (MRI) and Electroencephalogram (EEG) scans and reports.

\section{THE VARIED EFFECTS OF BILINGUALISM ON LANGUAGE PROCESSING}

The analytic research synthesis conducted on the studies reviewed found that results and outcomes on the effects of bilingualism towards language processing were varied and differentiated based on the variables measured. Studies that (Filippi et al., 2015; Havy, Bouchon \& Nazzi, 2016; Zirnstein, Hell \& Kroll, 2019; Abu Rabia, 2019) have reported various advantages of the bilingual experience in language processing found evidence of superior comprehension occurring even in the midst of interference (Filippi et al., 2015), efficiency in word learning (Havy, Bouchon \& Nazzi, 2016), better predictive skills despite decline in working memory (Zirnstein, Hell \& Kroll, 2019) and better metacognitive reading strategies (Rabia, 2019) However, disadvantages of the bilingual experience in language processing have also been revealed. For instance, the researches reviewed have concluded that there is an increase in tip of tongues among unimodal bilinguals, greater challenges in phonetic acquisition, cross-linguistic interference (Emmorey, Giezen \& Gollan, 2016; Havy et al., 2016; Salleh et al., 2016). On the other hand, there were also studies that were reviewed which reported no significant findings for the effect of bilingualism on 


\section{L: The Southeast Asian Journal of English Language Studies - Vol 26(1): 18 - 31 \\ http://doi.org/10.17576/3L-2020-2601-02}

language processing. For example, Kroll, Dussias, Bice and Perrotti (2015) revealed that there is an absence of the bilingual effect in many studies conducted among young adults.

Most of the research done regarding the effects of bilingualism on internal language processing has seen advantages which stems from the bilingual experience. For instance, in the study conducted by Bialystok (2017), it is found that the bilingual experience modifies the structure of the brain that is related to language processing due to the joined activation of language in the bilingual brain which requires inhibition and selection and the benefits extends beyond just one region. Therefore, both younger and older bilinguals are able to outperform monolinguals when it comes to tasks which require the use of the executive function, which also controls language processing. Similarly, Hämäläinen, Sairanen, Leminen and Lehtonen (2017) also reported advantages through a MRI scan and found that major language-related white matter trajectories contained bilingualism-induced modulations in which the most notable ones were along the left section of the arcuate fasciculus as well as an increased density which is in line with the findings of Pliatsikas, DeLuca, Moschopoulou and Saddy (2016) as well as Zirnstein, Hell and Kroll (2019) which revealed an expansion and increased thickness in various subcortical structures compared to monolinguals as well as a significant reshape in the caudate nucleus. However, the research conducted by White, Titione, Genesee and Steinhauer (2017) have reported no noteworthy differences or results among both native and late L2 learners in both accuracy and categorizing syllables with non-native phonological contrast particularly in their neurocognitive processes.

\section{METHODOLOGICAL APPROACHES IN THE BILINGUALISM AND LANGUAGE PROCESSING LITERATURE}

The current research analysis and synthesis revealed the many different methodological approaches as well as variations that have been employed by the researchers throughout the chosen articles which are most commonly task-based in order to determine how the bilingual experience plays a role in language processing. Some of the most common tasks used in the bilingualism literature are Sentence Stimuli Task in determining whether previous sentence was true or false, Fluency Task, Operation Span Task used to test the memory of letters while solving math problems, as well as a Cognitive Task Battery known as the AX-CPT test, Lexical Decision Task, Sematic Judgement Task, Picture Vocabulary Task, Flanker task as well as the Letter Number Sequencing Task (Table 1). All these tasks are utilized particularly in determining how bilingualism affects language processing through executive function or cognition such as in reading comprehension or cognitive development when learning a second language (Zirnstein et al., 2019; Legault, Grant \& Fang, 2019).

TABLE 1. Commonly employed tasks and in the bilingualism and language processing study

\begin{tabular}{ll}
\hline Tasks & \multicolumn{1}{c}{ Aim } \\
\hline Sentence Stimuli Task & Examines judgement of misleading information \\
Fluency Task & Examines efficiency of word retrieval \\
Operation Span Task & To test working memory \\
Cognitive Task Battery (AX-CPT & To test cognitive control in context processing while maintaining \\
Test) & goals \\
Lexical Decision Task & To examine the speed in classification of words and non-words \\
Semantic Judgement Task & Examine how semantics is embodied in memory \\
Picture Vocabulary Task & Measures receptive vocabulary \\
Flanker Task & To test inhibition ability of inappropriate responses \\
Letter Number Sequencing Task & Measures working memory capacity \\
\hline
\end{tabular}




\section{L: The Southeast Asian Journal of English Language Studies - Vol 26(1): 18 - 31 \\ http://doi.org/10.17576/3L-2020-2601-02}

Some other task-based approaches involve the use of pseudo-words. Both Havy, Bouchan and Nazzi (2016) as well as White, Titione, Genesse and Steinhauer (2017), have employed the use of pseudo-words in which the former implemented an object and pseudo-word matching task where participants are required to match the objects labelled with pseudo-words after they were presented to the participants in order to learn how bilinguals processed phonetics when learning words. All objects and pseudo-words had similar phonetic features. Similarly, White, Titione, Genesee and Steinhauer utilized pseudo-words by asking participants to click on the screen each time they heard a pseudo-word after being presented with a set of words during a semantic categorization task while continuous EEG was being recorded. Another task-based approach can be seen in the study conducted by Filippi et al. (2015) in testing out the control of linguistic interference during comprehension of verbal language. The researchers (Filippi et al., 2015) employed a sentence interpretation task in which the participants were presented with a combination of visual stimuli as well as auditory sentences of different complexity which might contain linguistic interference.

Most questionnaires or surveys used in the bilingualism and language processing literature are carried out as a pre-screening test in order to ensure the participants met with certain criteria. Majority of the research done from the 20 articles made sure that participants took a languagebackground questionnaire in order to assess the participant's background which gives information about the participant's age of acquisition, language learned or use and also to ensure they are in an optimal condition mentally before they are able to participate in the experiment especially for EEG recordings and MRI scans. These questionnaires are known as the Language History Questionnaire and Mini-Mental State Exam (White, Titione, Genesee \& Steinhauer, 2017; Hämäläinen, Sairanen, Leminen \& Lehtonen, 2017; Zirnstein et al., 2019; Legault et al., 2019; Abu Rabia, 2019). Abu Rabia (2019) also employed the use of questionnaire which are the English Proficiency Test as well as the Metacognitive Reading Strategies Questionnaire in studying how different degrees of bilingualism affect metacognitive linguistic. The use of these questionnaires especially for prescreening have shown to be a vital as such assessments produces independent variables used in examining correlation or prediction of performances (Li, Sepanski, \& Zhao, 2006; Soh, 2016, 2017; Mihat, Azman \& Soh, 2018).

Although observations are rarely used, it was employed by a few of the studies reviewed. Salleh et al. (2016) employed the use of observation through audio and video recordings coupled with a picture-based task to observe how the bilingual experience affects plural expressions in a bilingual child. Likewise, Salleh, Kawaguchi and Biase (2019) also employed a similar technique in determining how linguistic environment has a role to play in affecting a bilingual child's plural expression. Paramesvaran and Lim (2018) also employed observation through audio recordings as well as interview sessions whether by group or individually when studying about code-switching practices in order to find out the teacher's and student's perspectives. In contrast, researchers have also employed a more physically evident approach which is the use or MRI scanners and EEG recordings. To find out how immersive bilingualism reshapes the core of the brain, Pliatsikas et al. (2016) took a MRI scan of bilinguals who have been immersed in an environment of their second language after a period of time. Hämäläinen1, Sairanen, Lemine and Lehtonen (2017) also employed the use of a MRI scanner in order to examine how two major language trajectories along the local white matter structures are affected by bilingualism. 


\section{LIMITATIONS AND CHALLENGES IN THE BILINGUALISM AND LANGUAGE PROCESSING} LITERATURE

A few limitation and challenges have been identified through this review. Much of what is researched on bilingualism and language processing is based on the theory of inhibition control which is considered to be an advantage resulting in superior executive function as proposed by Green (1998). However, the executive function has various other components as well such as working memory, planning and even conflict monitoring. Thus, it is not accurate to equate inhibition control as executive function as Valian (2015) suggests a need to redefine executive function because based on that theory, tasks employed are usually aimed at testing inhibition control as a means to measure executive function.

The many variations and differences in tasks have shown to be a challenge as well. The difference in tasks used including the many variations in tasks might attribute to inconsistent findings or results. This is because it is unclear which part of the task activates which component of the executive function or perhaps even employs different parts of cognition that is unrelated to the executive function. Therefore, many of the methodological problems need to be resolved in order to produce a set of consistent assessment tools as the variations in the task can influence the performance of a participant on that task (Valian, 2015; Filippi, D’Souza \& Bright, 2018). Even with consistent scientific methods such as MRI scanners and EEG recordings, the limitation lies in the cost of the equipment. According to Legault, Grant, Fang and Li (2019), funding especially for additional participants can be quite hard to attain as there is an exorbitant cost of MRI scanning. Therefore, researchers can only utilize data-sharing consortiums which might fulfil all the criteria needed in that particular research.

Another challenge posed in the literature is the many individual differences that need to be taken into account. In measuring executive function, individual variability plays a role not only in terms of background but even the activities done by individuals as some activities might be related to superior executive function such as socioeconomic status, immigrant status, education level, musical training and experience in action video games, genetics and environmental factors (Valian, 2015; Filippi, D’Souza \& Bright, 2018; Fricke, Zirnstein, Navarro-Torres \& Kroll, 2018). However, it will be a challenge in taking into account all the individual-level differences that would affect the participant's performance on tasks regarding executive function. Even within the bilingual context, individual differences such as age of acquisition, degree of bilingualism, linguistic environment can be a factor that affects the outcome of the performance (Hämäläinen et al., 2017; Pliatsikas et al., 2016; Salleh et al., 2016).

\section{SCARCE REPORT OF BILINGUALISM AND LANGUAGE PROCESSING IN THE LOCAL SCENE}

Current critical analysis has also revealed that there is scarce research done in Malaysia about bilingualism and language processing. Out of the 20 articles, only 4 were conducted in Malaysia with only 2 of them researching about bilingualism in the context of language processing. However, the 2 studies conducted about bilingualism and language processing which are by Salleh, Kawaguchi, Jones and Biase (2016) as well as Salleh, Kawaguchi and Biase (2019), cannot be an accurate representation of the trend regarding bilingualism and language processing in Malaysia due to various reasons. The reasons being that the later study is actually a longitudinal study conducted on the same participant as a follow up study and in both the studies, the undeniable limitation is the generalization of findings based on a single bilingual subject as admitted by the researchers themselves (Salleh et al., 2016; Salleh, Kawaguchi \& Biase, 2019). Therefore, it is 


\section{L: The Southeast Asian Journal of English Language Studies - Vol 26(1): 18 - 31 \\ http://doi.org/10.17576/3L-2020-2601-02}

evident that there is a lack of research and studies done on bilingualism and language processing in Malaysia.

With Malaysia being a multiracial county, much of the focus on bilingualism has been placed in the context of education policies. For instance, the research studies done by Chan and Abdullah (2015), and Philip, Tan and Jandar (2019) focused on the relationship between bilingualism in Malaysia and language education policies as well as the perception of teachers on bilingualism. Similarly, the study conducted by Paramesvaran and Lim (2018) targets the perception of both teachers and students on the use of code-switching in a classroom setting. Chan and Abdullah have revealed that teachers mostly view bilingualism as of no consequence and with a low positive attitude. The authors also have pointed out though bilingual education in introduced and implemented in Malaysia, the Bahasa Malaysia language is still dominant and heavily emphasised which leads to the deterioration of English. However, Paramesvaran and Lim have reported that teacher's and student's perception of code-switching in a classroom setting differed. Students with a lower proficiency in a certain language found code-switching extremely helpful (Meganathan, Yap, Paramasivam \& Jalaluddin, 2019). Hence, it can be said that not only is there an overall lack of research done on bilingualism and language processing, but also the general lack of understanding of the importance of bilingualism in Malaysia.

\section{DISCUSSION}

The overall review and synthesis of the studies selected have revealed that the study of bilingualism and language processing has evolved from focusing on the effects of bilingualism on external processing of language towards internal language processing as well as the study on other dimensions such as factors that affect bilingualism and language processing including individual differences. The shift of focus towards internal language processing in the study of bilingualism is in tandem with the conclusion of Kroll, Dussias, Bice and Perroti (2015) stating that intent of current research is to unveil the mechanisms that are responsible for the effects of bilingualism by attempting to seize language processing during its process. This is important as Valian (2015) has detailed how inhibition has often been used to as a generalization of executive function which is considered inaccurate as the executive function is comprised of many other functions. Therefore, the need to accurately discover and describe the exact section of the executive function being employed is present. Findings in trends also revealed that there is a lack of research conducted among young adults as majority of the studies were targeted at either children or adults. Although Bialystok (2017) attributes this to the lack of effect of the bilingual experience in young adults due to them being in the state of peak performance in executive function, it is still unclear as to whether or not the hypothesis is true due to the scarce amount of research.

Through this critical review, the results have also indicated that there is a variety of outcomes on the studies carried out whether advantage, disadvantage or showing no significance on the effect of bilingualism and language processing both internal and external. This trend of inconsistency in results is one that has beset the study of bilingualism, an area which has been continually discussed over the decades. However, current understanding proposes the view that inconsistency and variety in results is suggested by Valian (2015) to be expected as there is still a lack in the understanding of executive function as the tasks employed coupled with individual differences such as immigrant status, level education, age of acquisition and degree of bilingualism which has proven difficult to control. Hence, it would be beneficial for the research of bilingualism to examine the role of such factors which influence the executive function in relation to 
bilingualism and language processing. Fricke, Zirnstein, Navarro-Torres and Kroll (2018) have shared similar views concluding that the relationship between individual accumulated experience and language processing is promised to be elucidated by future research. Based on the studies reviewed, it is evident that there remains a dearth in research in these mentioned areas.

Results have also indicated a need for various methodological uncertainties to be resolved and employed on a large scale as Filippi, D'Souza and Bright (2018) have brought to light the problem of questionable methodological rigor in the study of bilingualism. In many studies, various tasks such as the Flanker Task have been adapted and employed in different variations which can be said to contribute to the inconsistency in results. Valian (2015) has thoroughly explained that tasks employed in measuring executive function unavoidably stimulate mechanisms that do not belong to the executive function. Therefore, it is unclear as to which exact part of the tasks taps executive functions and which does not especially when a variation of a task is employed. However, limitations presents itself in that in spite of the emerging methods such as MRI scanners and EEG recordings, which are regarded as more insightful and reliable, such methods are constrained by its exorbitant cost. Hence, there exists an important need for researchers to re-evaluate and reconsider the methodological approaches used in studying bilingualism and language processing.

Finally, this analysis and synthesis of reviewed studies has found a huge gap in the research of bilingualism and language processing in Malaysia, where most of the research conducted were about bilingualism in the context of education as well as pedagogy and language policies. Studies that focus on bilingualism in the context of education aimed to contribute findings towards the education policy or even in a classroom setting. Thus, it is clear that there still exists a general lack in understanding how the bilingual mind processes and learn languages among bilinguals in Malaysia.

\section{CONCLUSION}

The present systematic review of 20 articles on bilingualism and language processing has revealed to us that there are still many aspects of bilingualism that needs to be researched on particularly in the context of language processing coupled with a lack of critical syntheses carried out. Findings are taken from an analysis and synthesis based on the trends, outcomes, methodological approaches, challenges and limitations. First, the review has indicated that the study of bilingualism and language processing is now focused on internal language processing as well as the study on other dimensions such as individual differences. Secondly, there is a variation in outcomes which entails advantages, disadvantages and no significant findings due to individual differences and the uncertainties in methodological variations. Third, huge amounts of variety in methodological approaches have been employed in studying the effects of bilingualism and language processing bringing attention to the need for standardization. Fourth, the challenges and limitations of the literature have revealed itself in the unclear definition of executive function, the inconsistency in tasks used as well as individual differences. Finally, scarce studies of bilingualism and language processing exist in Malaysia.

This review has presented findings and recommendations to assist researchers in the overall understanding of the current literature on bilingualism and language processing as well as provide several suggestions for future research. With the understanding of the current literature, future research and studies can now focus on studying how individual differences such as the degree of bilingualism, level of education and even age of acquisition affect the outcomes in language 


\section{L: The Southeast Asian Journal of English Language Studies - Vol 26(1): 18 - 31 \\ http://doi.org/10.17576/3L-2020-2601-02}

processing. Additionally, there is a lack of studies conducted on participants from the young adult age group as demonstrated in the findings. Besides that, researchers can now be aware of how methodological variations can affect performance and in doing so re-evaluate or incorporate a more coherent and controlled approach such as eye-tracking (Hasrul, Hazita \& Azizah, 2018; Sarah Yusri \& Soh, 2019). Lastly, we have concluded the lack of studies done in Malaysia pens a huge gap in which more research can be done in order to fill in that gap.

\section{ACKNOWLEDGEMENTS}

This research was supported by the research grant FRGS/1/2017/SSI01/UKM/01/

\section{REFERENCES}

Abu Rabia, S. (2019). The effect of degrees of bilingualism on metacognitive linguistic skills. International Journal of Bilingualism, 23(5), 1064-1086. https://doi.org/10.1177/1367006918781060

Antoniou, M. (2019). The advantages of bilingualism debate. Annual Review of Linguistics, 5, 1-21.

B. Philip, Tan, K. H. \& W. A. Jandar. (2019). Exploring Teacher Cognition in Malaysian ESL Classrooms. 3L: The Southeast Asian Journal of English Language Studies, 25(4), 156 - 178.

Bacca, J., Baldiris, S., Fabregat, R., Graf, S. \& Kinshuk. (2014). Augmented Reality Trends in Education: A Systematic Review of Research and Applications. Educational Technology \& Society, 17 (4), $133-149$.

Baran, E. (2014). A Review of Research on Mobile Learning in Teacher Education. Educational Technology \& Society, $17(4), 17-32$.

Bialystok, E. (2017). The bilingual adaptation: How minds accommodate experience. Psychological Bulletin 143(3), 233-262. doi:10.1037/bul0000099

Bialystok, E. \& Martin, M. M. (2004). Attention and inhibition in bilingual children: Evidence from the dimensional change card sort task. Developmental Science, 7, 325-339. https://doi.org/10.1111/j.1467-7687.2004.00351.x

Bialystok, E., Craik, F. I. M. \& Freedman, M. (2007). Bilingualism as a protection against the onset symptoms of dementia. Neuropsychologia, 45, 459-464. https://doi.org/10.1016/j.neuropsychologia.2006.10.009

Broos, W. P. J., Duyck, W. \& Hartsuiker, R. J. (2018). Are Higher-Level Processes Delayed in Second Language Word Production? Evidence from Picture Naming and Phoneme Monitoring. Language, Cognition and Neuroscience 33(10), 1219-1234. DOI:10.1080/23273798.2018.1457168

Bruin, A. D., Treccani, B. \& Sala, S. D. (2015). Cognitive Advantage in Bilingualism: An Example of Publication Bias? Psychological Science. 26(1), 99-107. https://doi.org/10.1177/0956797614557866

Chan, Swee Heng \& Abdullah, Ain Nadzimah. (2015). Bilingualism in Malaysia: language education policy and local needs. Pertanika Journal of Social Sciences \& Humanities, 23, 55-70. ISSN 0128-7702

Costa, A., Hernandez, M., Faidella, C. J. \& Galles, S. N. (2009). On the bilingual advantage in conflict processing: now you see it, now you don't. Cognition, 113, 135-149. https://doi.org/10.1016/j.cognition.2009.08.001

Emmorey, K., Giezen, M. \& Gollan, T. (2016). Psycholinguistic, cognitive, and neural implications of bimodal bilingualism. Bilingualism: Language and Cognition, 19(2), 223-242. doi:10.1017/S1366728915000085

Filippi, R., D’Souza, D. \& Bright, P. (2018). A developmental approach to bilingual research: The effects of multilanguage experience from early infancy to old age. International Journal of Bilingualism, 23(5), $1195-1207$.

Filippi, R., Morris, J., Richardson, F., Bright, P., Thomas, M., Karmiloff-Smith, A.Marian, V. (2015). Bilingual children show an advantage in controlling verbal interference during spoken language comprehension. Bilingualism: Language and Cognition, 18(3), 490-501. doi:10.1017/S1366728914000686

Fricke, M., Zirnstein, M., Navarro-Torres, C. \& Kroll, J. (2018). Bilingualism reveals fundamental variation in language processing. Bilingualism: Language and Cognition, 22(1), 200-207. Green, D. W. (1998). Mental control of the bilingual lexico-semantic system. Bilingualism: Language and Cognition, 1, 67-81. https://doi.org/10.1017/S1366728998000133

Hämäläinen, S., Sairanen, V., Leminen, A. \& Lehtonen, M. (2017). Bilingualism modulates the white matter structure of language-related pathways. NeuroImage, 152, 249-257. DOI: 10.1016/j.neuroimage.2017.02.081

Hasrul, K., Hazita, A., Azizah, M., Z. (2018). Research Trend in the Practice of Differentiated Instruction. The Journal of Social Sciences Research, 4(12), 648-668. https://doi.org/10.32861/jssr.412.648.668

Hamers, J. F., \& Blanc, M. H. A. (1983). Bilinguality \& bilingualism. New York, NY: Cambridge University Press. 


\section{L: The Southeast Asian Journal of English Language Studies - Vol 26(1): 18 - 31 \\ http://doi.org/10.17576/3L-2020-2601-02}

Havy, M., Bouchon, C. \& Nazzi, T. (2016). Phonetic processing when learning words: The case of bilingual infants. International Journal of Behavioral Development, 40(1), 41-52. DOI: 10.1177/0165025415570646

Hsieh, H. F. \& Shannon, S. (2005). Three approaches to qualitative content analysis. Qualitative Health Research, 15, 1277-1288. https://doi.org/10.1177/1049732305276687

Kroll, J. F., Dussias, P. E., Bice, K. \& Perrotti, L. (2015). Bilingualism, Mind, and Brain. Annual review of linguistics, 1, 377-394. doi:10.1146/annurev-linguist-030514-124937

Legault, J., Grant, A., Fang, S.-Y. \& Li, P. (2019). A Longitudinal Investigation of Structural Brain Changes During Second Language Learning. Brain and Language, 197(104661), 1-46.

Leikin, M. (2012). The effect of bilingualism on creativity: Developmental and educational perspectives. International Journal of Bilingualism, 17, 431-447. https://doi.org/10.1177/1367006912438300

Mihat, W., Azman, H. \& Soh, O.K. (2018). Bringing reading research in multilingual Nusantara into a new direction through eye-tracking. Journal of Nusantara Studies, $3(2), \quad 107-\quad 123$. http://dx.doi.org/10.24200/jonus.vol3iss2pp107-123

Opfer, V. \& Pedder, D. (2011). Conceptualizing teacher professional learning. Review of Educational Research, 81(3), 376-407

Paramesvaran, M. D. \& Jia, Wei Lim. (2018). Code-switching practices in a Malaysian multilingual primary classroom from teacher and student perspectives. Indonesian Journal of Applied Linguistics, 8(2), $254-264$. doi: 10.17509/ijal.v8i2.13273

Pavani, M., Yap, N. T., Shamala, P. \& I. Jalaluddin. (2019). Incidental and Intentional Learning of Vocabulary among Young ESL Learners. 3L: The Southeast Asian Journal of English Language Studies, 25(4), 51 - 67 http://doi.org/10.17576/3L-2019-2504-04

Pliatsikas, C., Deluca, V., Moschopoulou, E. \& Saddy, J. D. (2016). Immersive Bilingualism Reshapes the Core of the Brain. Brain Structure and Function, 222(4), 1785-1795. DOI: 10.1007/s00429-016-1307-9

Rossi, E., Diaz, M., Kroll, J. F. \& Dussias, P. E. (2017). Late Bilinguals Are Sensitive to Unique Aspects of Second Language Processing: Evidence from Clitic Pronouns Word-Order. Frontiers in Psychology, 8(342), 1-13. doi: 10.3389/fpsyg.2017.00342

Salleh, R., Kawaguchi, S. \& Biase, B. D. (2019). A Case Study on the Acquisition of Plurality in a Bilingual MalayEnglish Context-bound Child. GEMA Online ${ }^{\circledR}$ Journal of Language Studies, 19(3), 22-42. http://doi.org/10.17576/gema-2019-1903-02

Salleh, R., Kawaguchi, S., Jones, C. \& Biase, B.D. (2016). The development of plural expressions in a Malay-English bilingual Child. Asiatic: IIUM Journal of English Language and Literature, 10(2), 60-81. ISSN: 1985-3106.

Sarah Yusri \& Or-Kan, Soh. (2019). Examining University Students' Reading Performances and Behaviors with the Use of Eye-Trackers. International Journal of Academic Research in Business and Social Sciences, 9(8), 114-123. DOI: 10.6007/IJARBSS/v9-i8/6221

Scandoval, T. C., Gollan, T. H., Ferreira, V. S. \& Salmon, D. P. (2010). What causes the bilingual disadvantage in

verbal fluency? The dual-task analogy. Bilingualism: Language and Cognition, 13, $231-252$. https://doi.org/10.1017/S1366728909990514

Soh, Or-Kan. (2016). Examining the reading behaviours and performances of sixth-graders for reading instruction: evidence from eye movements. Journal of e-Learning and Knowledge Society, 12(4), 63-79.

Soh, Or-Kan. (2017). Processing academic science reading texts through context effects: Evidence from eye movements. EURASIA Journal of Mathematics, Science and Technology Education, 13(3), 771-790.

Suri, H. \& Clarke, D. (2009). Advancements in research synthesis methods: From a methodologically inclusive perspective. Review of Educational Research, 79(1), 395-430.

Valian, V. (2015). Bilingualism and cognition. Bilingualism: Language and Cognition, 18(1), 3-24. doi:10.1017/S1366728914000522

Webster, J. \& Watson, R. (2002). Analyzing the past to prepare for the future: writing a literature review. Management Information Systems Quarterly, 26, xiii-xxiii.

White, E., Titone, D., Genesee, F. \& Steinhauer, K. (2017). Phonological processing in late second language learners: The effects of proficiency and task. Bilingualism: Language and Cognition, 20(1), 162-183. doi:10.1017/S1366728915000620

Zirnstein, M., van Hell, J. G. \& Kroll, J. F. (2019). Cognitive control and language ability contribute to online reading comprehension: Implications for older adult bilinguals. International Journal of Bilingualism, 23(5), 971985. https://doi.org/10.1177/1367006918763143 


\section{L: The Southeast Asian Journal of English Language Studies - Vol 26(1): 18 - 31 \\ http://doi.org/10.17576/3L-2020-2601-02}

\section{APPENDIX}

An analysis of studies on bilingualism and language processing $(n=20)$

\begin{tabular}{|c|c|c|c|c|c|}
\hline Study & Aim of study & Method & $\begin{array}{l}\text { Participant } \\
\text { information }\end{array}$ & Data Sources & Conclusion \\
\hline $\begin{array}{l}\text { Kroll, Dussias, } \\
\text { Bice \& Perrotti } \\
(2015)\end{array}$ & $\begin{array}{l}\text { How bilingualism } \\
\text { effects L1 \& L2 } \\
\text { language influence \& } \\
\text { its consequences }\end{array}$ & $\begin{array}{l}\text { Qualitative } \\
\text { review }\end{array}$ & - & Journal Articles & $\begin{array}{l}\text { L1 and L2 are } \\
\text { interconnected \& } \\
\text { affect each other as } \\
\text { well as cognition. }\end{array}$ \\
\hline Valian (2015) & $\begin{array}{l}\text { Examines effects of } \\
\text { bilingualism on } \\
\text { executive function \& } \\
\text { cognitive reserve }\end{array}$ & $\begin{array}{l}\text { Qualitative } \\
\text { review }\end{array}$ & - & Journal Articles & $\begin{array}{l}\text { Inhibition cannot } \\
\text { represent executive } \\
\text { function \& individual } \\
\text { differences to be } \\
\text { considered }\end{array}$ \\
\hline $\begin{array}{l}\text { Filippi et al. } \\
\text { (2015) }\end{array}$ & $\begin{array}{l}\text { Examine bilingual } \\
\text { advantage in } \\
\text { controlling } \\
\text { interference in } \\
\text { auditory attention }\end{array}$ & Case study & $\begin{array}{l}20 \text { bilingual \& } \\
20 \text { monolingual } \\
\text { children (age } 7- \\
10)\end{array}$ & $\begin{array}{l}\text { Matching task, } \\
\text { Observation and } \\
\text { field notes }\end{array}$ & $\begin{array}{l}\text { Bilingual children are } \\
\text { able to control } \\
\text { interference }\end{array}$ \\
\hline $\begin{array}{l}\text { Chan \& } \\
\text { Abdullah } \\
(2015)\end{array}$ & $\begin{array}{l}\text { Examine bilingualism } \\
\text { in education policy \& } \\
\text { perception of teachers } \\
\text { on bilingualism }\end{array}$ & Mixed method & $\begin{array}{l}39 \text { language } \\
\text { teachers (age } \\
20-59)\end{array}$ & $\begin{array}{l}\text { Document \& } \\
\text { questionnaire } \\
\text { survey }\end{array}$ & $\begin{array}{l}\text { Bahasa Malaysia still } \\
\text { has strong influence \& } \\
\text { bilingualism not } \\
\text { perceived as a } \\
\text { significant }\end{array}$ \\
\hline $\begin{array}{l}\text { Emmorey, } \\
\text { Giezen \& } \\
\text { Gollan } \\
(2016)\end{array}$ & $\begin{array}{l}\text { Examine the nature of } \\
\text { language control in } \\
\text { bimodal bilinguals }\end{array}$ & $\begin{array}{l}\text { Qualitative } \\
\text { review }\end{array}$ & - & Journal articles & $\begin{array}{l}\text { Bimodal bilinguals } \\
\text { differ in activation of } \\
\text { non-target language \& } \\
\text { advantages compared } \\
\text { to unimodal bilinguals }\end{array}$ \\
\hline $\begin{array}{l}\text { Havy, Bouchon } \\
\& \text { Nazzi (2016) }\end{array}$ & $\begin{array}{l}\text { Provide insight of } \\
\text { bilingual's word } \\
\text { learning capacities }\end{array}$ & Case study & $\begin{array}{l}36 \text { bilingual } \\
\text { infants ( } 16 \text { moth } \\
\text { old) }\end{array}$ & $\begin{array}{l}\text { Object choosing } \\
\text { task, } \\
\text { Observation \& } \\
\text { field notes }\end{array}$ & $\begin{array}{l}\text { Advantage for } \\
\text { bilinguals whose } \\
\text { languages realize the } \\
\text { tested phonological } \\
\text { contrasts similarly at } \\
\text { the acoustic level. }\end{array}$ \\
\hline $\begin{array}{l}\text { Pliatsikas et al. } \\
\text { (2016) }\end{array}$ & $\begin{array}{l}\text { Effects of } \\
\text { bilingualism on the } \\
\text { subcortical structures }\end{array}$ & Case study & $\begin{array}{l}20 \text { L2 English } \\
\text { Speakers \& } 17 \\
\text { Greek L2 } \\
\text { English learners }\end{array}$ & $\begin{array}{l}\text { MRI scans, } \\
\text { Observation \& } \\
\text { field notes }\end{array}$ & $\begin{array}{l}\text { Degrees of immersion } \\
\text { affects the subcortical } \\
\text { structures }\end{array}$ \\
\hline $\begin{array}{l}\text { Salleh et al. } \\
\text { (2016) }\end{array}$ & $\begin{array}{l}\text { Early bilingual } \\
\text { development of plural } \\
\text { marking }\end{array}$ & Case study & $\begin{array}{l}1 \text { Malay- } \\
\text { English } \\
\text { bilingual child } \\
\text { (age 3) }\end{array}$ & $\begin{array}{l}\text { Observations } \\
\text { via video \& } \\
\text { audio recording } \\
\text { and field notes }\end{array}$ & $\begin{array}{l}\text { The child developed } \\
\text { simultaneously, two } \\
\text { different plural } \\
\text { systems in English and } \\
\text { Malay. }\end{array}$ \\
\hline $\begin{array}{l}\text { White, Titone, } \\
\text { Genesee \& } \\
\text { Steinhauer } \\
\text { (2017) }\end{array}$ & $\begin{array}{l}\text { Examine } \\
\text { morphosyntactic } \\
\text { processing in relation } \\
\text { to proficiency }\end{array}$ & $\begin{array}{l}\text { Mixed } \\
\text { Method }\end{array}$ & $\begin{array}{l}15 \text { monolingual } \\
\text { English } \\
\text { Speakers \& } 15 \\
\text { native French- } \\
\text { English L2 } \\
\text { speakers ( age } \\
\text { 20-35) } \\
\end{array}$ & $\begin{array}{l}\text { EEG recording, } \\
\text { observation \& } \\
\text { field notes }\end{array}$ & $\begin{array}{l}\text { Neurocognitive } \\
\text { mechanisms } \\
\text { supporting L2 } \\
\text { processing are not } \\
\text { qualitatively different } \\
\text { in native speakers and } \\
\text { late L2 learners. }\end{array}$ \\
\hline $\begin{array}{l}\text { Bialystok } \\
(2017)\end{array}$ & $\begin{array}{l}\text { Investigate } \\
\text { relationship between } \\
\text { bilingualism \& } \\
\text { cognition in various } \\
\text { age groups }\end{array}$ & $\begin{array}{l}\text { Qualitative } \\
\text { review }\end{array}$ & - & Journal articles & $\begin{array}{l}\text { Both younger and } \\
\text { older bilinguals } \\
\text { generally outperform } \\
\text { monolinguals on a } \\
\text { range of tasks that fall } \\
\text { broadly within the } \\
\text { category of executive } \\
\text { function. }\end{array}$ \\
\hline
\end{tabular}




\begin{tabular}{|c|c|c|c|c|c|}
\hline $\begin{array}{l}\text { Hämäläinen } 1, \\
\text { Sairanen, } \\
\text { Leminen \& } \\
\text { Lehtonen } \\
(2017)\end{array}$ & $\begin{array}{l}\text { Examine how early } \\
\text { bilingualism affects } \\
\text { local white matter } \\
\text { structures along two } \\
\text { major language } \\
\text { trajectories }\end{array}$ & $\begin{array}{l}\text { Mixed } \\
\text { Method }\end{array}$ & $\begin{array}{l}15 \text { early } \\
\text { Finnish- } \\
\text { Swedish \& } 15 \\
\text { late English- } \\
\text { Finnish } \\
\text { bilinguals } \\
\end{array}$ & $\begin{array}{l}\text { MRI scans, } \\
\text { observation \& } \\
\text { field notes }\end{array}$ & $\begin{array}{l}\text { late bilingual speakers } \\
\text { are more likely to } \\
\text { exhibit extreme left } \\
\text { lateralization pattern } \\
\text { than early bilinguals }\end{array}$ \\
\hline $\begin{array}{l}\text { Rossi, Diaz, } \\
\text { Kroll, Dussias } \\
(2017)\end{array}$ & $\begin{array}{l}\text { Study sensitivity to } \\
\text { word order for clitic } \\
\text { pronouns in late } \\
\text { English-Spanish } \\
\text { bilinguals }\end{array}$ & Quantitative & $\begin{array}{l}25 \text { native } \\
\text { Spanish } \\
\text { speakers with } \\
\text { proficient } \\
\text { English \& } 25 \\
\text { late English- } \\
\text { Spanish } \\
\text { bilinguals }\end{array}$ & $\begin{array}{l}\text { Self-paced } \\
\text { reading }\end{array}$ & $\begin{array}{l}\text { Late bilinguals can } \\
\text { process aspects of } \\
\text { grammar in L2- } \\
\text { specific linguistic } \\
\text { constructions even } \\
\text { when subtle }\end{array}$ \\
\hline $\begin{array}{l}\text { Filippi, } \\
\text { D’Souza \& } \\
\text { Bright (2018) }\end{array}$ & $\begin{array}{l}\text { Provide further } \\
\text { insight on multi- } \\
\text { language experience } \\
\text { on cognitive } \\
\text { development }\end{array}$ & $\begin{array}{l}\text { Qualitative } \\
\text { review }\end{array}$ & - & Journal articles & $\begin{array}{l}\text { There is a need for } \\
\text { large-scale, } \\
\text { longitudinal studies \& } \\
\text { inclusion of atypical } \\
\text { development }\end{array}$ \\
\hline $\begin{array}{l}\text { Fricke, } \\
\text { Zirnstein, } \\
\text { Navarro-Torres } \\
\text { \& Kroll (2018) }\end{array}$ & $\begin{array}{l}\text { Examine individual } \\
\text { differences in } \\
\text { language processing }\end{array}$ & $\begin{array}{l}\text { Qualitative } \\
\text { review }\end{array}$ & - & Journal articles & $\begin{array}{l}\text { Individual-level } \\
\text { variability play a role } \\
\text { in determining } \\
\text { performance on tasks } \\
\text { of executive function }\end{array}$ \\
\hline $\begin{array}{l}\text { Paramesvaran } \\
\& \text { Lim (2018) }\end{array}$ & $\begin{array}{l}\text { Examine teacher's } \\
\text { reasons for practicing } \\
\text { codeswitching \& } \\
\text { student's perspective }\end{array}$ & Qualitative & $\begin{array}{l}1 \text { English } \\
\text { teacher \& } 3 \\
\text { multilingual } \\
\text { students (age } \\
11 \text { ) }\end{array}$ & $\begin{array}{l}\text { Observation via } \\
\text { video \& } \\
\text { interview }\end{array}$ & $\begin{array}{l}\text { Code-switching } \\
\text { practice used to } \\
\text { reinforce knowledge \& } \\
\text { participation }\end{array}$ \\
\hline $\begin{array}{l}\text { Broos, Duyck } \\
\text { \& Hartsuiker } \\
(2018)\end{array}$ & $\begin{array}{l}\text { To find out delay due } \\
\text { to difficulties in } \\
\text { higher-level processes } \\
\text { of L2 speakers }\end{array}$ & Qualitative & $\begin{array}{l}35 \text { monolingual } \\
\text { English L1 } \\
\text { speakers \& } 48 \\
\text { bilingual Dutch- } \\
\text { English } \\
\text { speakers }\end{array}$ & $\begin{array}{l}\text { Computer } \\
\text { picture word } \\
\text { task }\end{array}$ & $\begin{array}{l}\text { Delay in speech } \\
\text { production is situated } \\
\text { in a later stage }\end{array}$ \\
\hline $\begin{array}{l}\text { Zirnstein, Hell } \\
\text { \& Kroll (2019) }\end{array}$ & $\begin{array}{l}\text { Investigate how } \\
\text { bilingualism affects } \\
\text { prediction processes }\end{array}$ & $\begin{array}{l}\text { Mixed } \\
\text { Method }\end{array}$ & $\begin{array}{l}12 \text { bilinguals \& } \\
15 \\
\text { monolinguals } \\
\text { (age } 61-83 \text { ) } \\
\end{array}$ & $\begin{array}{l}\text { Observation, } \\
\text { field notes \& } \\
\text { EEG recordings }\end{array}$ & $\begin{array}{l}\text { Older adult bilinguals } \\
\text { are better in the highly } \\
\text { resource-demanding } \\
\text { task of predicting }\end{array}$ \\
\hline $\begin{array}{l}\text { Legault, Grant, } \\
\text { Fang \& Li } \\
(2019)\end{array}$ & $\begin{array}{l}\text { Examine changes in } \\
\text { cortical thickness } \\
\text { (CT) \& gray matter } \\
\text { volume (GMV) } \\
\text { among bilinguals }\end{array}$ & $\begin{array}{l}\text { Mixed } \\
\text { Method }\end{array}$ & $\begin{array}{l}24 \text { native } \\
\text { English } \\
\text { speakers with } \\
\text { intermediate } \\
\text { level of Spanish }\end{array}$ & $\begin{array}{l}\text { MRI Scans \& } \\
\text { matching task, } \\
\text { Flanker task, } \\
\text { Letter number } \\
\text { sequence task }\end{array}$ & $\begin{array}{l}\text { L2 learning-associated } \\
\text { lead to increases in CT } \\
\text { in two key regions } \\
\text { involved in lexico- } \\
\text { semantics \& cognitive } \\
\text { control }\end{array}$ \\
\hline $\begin{array}{l}\text { Salleh, } \\
\text { Kawaguchi, } \\
\text { Biase (2019) }\end{array}$ & $\begin{array}{l}\text { Examine the role of } \\
\text { linguistic environment } \\
\text { in the development of } \\
\text { plural expressions in } \\
\text { bilingual child }\end{array}$ & Qualitative & $\begin{array}{l}1 \text { English- } \\
\text { Malay bilingual } \\
\text { child (age 4) }\end{array}$ & $\begin{array}{l}\text { Observation via } \\
\text { video recording, } \\
\text { interview }\end{array}$ & $\begin{array}{l}\text { Linguistic environment } \\
\text { is an important } \\
\text { variable in a child's } \\
\text { bilingual development } \\
\& \text { performance }\end{array}$ \\
\hline Rabia (2019) & $\begin{array}{l}\text { Examine the } \\
\text { metacognitive } \\
\text { performance of } \\
\text { degrees of } \\
\text { bilingualism in } \\
\text { linguistic \& } \\
\text { metalinguistic } \\
\text { awareness }\end{array}$ & Quantitative & $\begin{array}{l}120 \text { Hebrew- } \\
\text { Russian school } \\
\text { students (age } \\
12-13 \text { ) }\end{array}$ & Questionnaire & $\begin{array}{l}\text { Metacognitive } \\
\text { linguistic advantage } \\
\text { only in balance \& } \\
\text { dominant bilinguals. }\end{array}$ \\
\hline
\end{tabular}

